\title{
ДОСВІД КАФЕДРИ МЕДИЧНОГО ТА ФАРМАЦЕВТИЧНОГО ПРАВА, ЗАГАЛЬНОЇ І КЛІНІЧНОЇ ФАРМАЦІЇ ХАРКІВСЬКОЇ МЕДИЧНОЇ АКАДЕМІЇ ПІСЛЯДИПЛОМНОЇ ОСВІТИ ЩОДО НАВЧАЛЬНОГО ПРОЦЕСУ В ПЕРІОД КАРАНТИНУ, СПРИЧИНЕНОГО COVID-19
}

\section{EXPERIENCE OF THE DEPARTMENT OF MEDICAL AND \\ PHARMACEUTICAL LAW, GENERAL AND CLINICAL PHARMACY OF THE KHARKIV MEDICAL ACADEMY OF POSTGRADUATE EDUCATION CONCERNING THE EDUCATIONAL PROCESS DURING THE QUARANTINE PERIOD CAUSED BY COVID-19}

\begin{abstract}
Вікторія Шаповалова, доктор фармацевтичних наук, професор, Харківська медична академія післядипломної освіти, Харків, Україна; Валерій Шаповалов, доктор фармацевтичних наук, професор, ТзОВ «Львівський медичний інститут», Львів, Україна; Валентин Шаповалов, доктор фармацевтичних наук, професор, Адвокатське об'єднання «Апофеоз», Харків, Україна; Аліна Осинцева, кандидат фармацевтичних наук, Харківська медична академія післядипломної освіти, Харків, Україна; Сергій Негрецький, кандидат фармацевтичних наук, Харківська медична академія післядипломної освіти, Харків, Україна; Анатолій Деркач, кандидат фармацевтичних наук, доцент, Харківська медична академія післядипломної освіти, Харків, Україна; Олександр Січкаренко, Харківська медична академія післядипломної освіти, Харків, Україна; Тетяна Бичкова, Харківська медична академія післядипломної освіти, Харків, Україна
\end{abstract}

Abstract. The experience of tutor coaching staff of the Department of Medical and Pharmaceutical Law, General and Clinical Pharmacy of the Kharkiv Medical Academy of Postgraduate Education concerning the educational process during the quarantine caused by COVID-19 disease due to coronavirus SARS-CoV2 , on the example of advanced training cycles using distance learning technologies. It is noted that antiepidemic measures are observed in Kharkiv Medical Academy of Postgraduate Education in order to prevent the spread of COVID-19 in the educational process. The Department of Medical and Pharmaceutical Law,
General and Clinical Pharmacy successfully conducts cycles for doctors and pharmacists using distance learning technologies. The positive feedback from doctors and pharmacists on the organization of distance learning by the Department of Medical and Pharmaceutical Law, General and Clinical Pharmacy of the Kharkiv Medical Academy of Postgraduate Education was emphasized $(95 \%$ of students were satisfied with the advanced training courses).

Keywords: COVID-19 coronavirus, quarantine, distance learning, doctors, pharmacists, advanced training, medical law, pharmaceutical law, forensic pharmacy.

Вступ. В Україні з 23.09.2021 по 31.12.2021 встановлено «жовтий» рівень епідемічної небезпеки, але темпи розповсюдження коронавірусу свідчать, що найближчим часом деякі регіони можуть перейти в «червону зону» [1]. 
Встановлення «жовтого» рівня щодо обмежень базується на Постанові Кабінету Міністрів України від 22.09.2021 p. N 981 «Про внесення змін до деяких актів Кабінету Міністрів України» [2]. Передбачено такі зміни:

- у розпорядження Кабінету Міністрів України від 25.03.2020 p. N 338 «Про переведення єдиної державної системи цивільного захисту у режим надзвичайної ситуації»- із змінами, внесеними постановою Кабінету Міністрів України від 11.08.2021 р. N 855 (Офіційний вісник України, 2021 р., N 67, ст. 4231), цифру і слово "1 жовтня" замінити цифрами і словом «31 грудня» [3];

- у постанову Кабінету Міністрів України від 09.12.2020 р. N 1236 «Про встановлення карантину та запровадження обмежувальних протиепідемічних заходів з метою запобігання поширенню на території України гострої респіраторної хвороби COVID-19, спричиненої коронавірусом SARS-CoV-2» (Офіційний вісник України, 2021 р., N 1, ст. 14 , N 5, ст. 272 , N 17, ст. 664 , N 27, ст. 1442 , N 31, ст. 1786, N 35, ст. 2100 , N 50, ст. 3075, N 54, ст. 3342, N 62, ст. 3926, N 67, ст. 4231) - із змінами, внесеними постановами Кабінету Міністрів України від 18.08.2021 p. N 889 та від 13.09.2021 p. N 954 [4].

Нижче наведено рисунок щодо нових карантинних обмежень - «жовтий рівень», що діють на території України з 23.09.2021 по 31.12.2021 (рис. 1).

Враховуючи відповідні обмеження в умовах пандемії коронавірусної хвороби, слід зазначити, що, сучасний рівень вищої медичної та фармацевтичної освіти прямо впливає на зайнятість лікарів та провізорів та їх матеріальний достаток тобто краще освічені фахівці, які своєчасно підвищують свою кваліфікацію, легше адаптуються к труднощам, організовують для себе i підлеглих привілейовані умови праці та сприяють тому щоб той, хто пильно, кваліфіковано і професіонально виконував свої професійні обов'язки - більше заробляв та мав високий матеріальний стимул. Разом 3 тим, рівень освіти та своєчасне підвищення кваліфікації позитивно пов'язано із тривалістю і якістю життя, здоров'ям та соціально-економічною та медико-фармацевтичною адаптацію і інтеграцією в умовах коронавірусної інфекції SARS-COV-2 [5-7].

Слід зазначити, що в системі правовідносин «лікар-пацієнт-провізор» краще освічені лікарі і провізори демонструють компетентність, а також забезпечують у своїй роботі високі морально-етичні та духовно-правові здібності, виконання конституційних прав людини, громадянина і пацієнта на принципах медичного та фармацевтичного права, що базуються на ст. 4 Закону України «Основи законодавства України про охорону здоров'я» [8-12].

Базовим нормативно правовим актом про встановлення карантину та запровадження обмежувальних протиепідемічних заходів з метою запобігання поширенню на території України гострої респіраторної хвороби COVID-19, спричиненої коронавірусом SARS-CoV-2 є постанова Кабінету Міністрів України від 9 грудня 2020 р. № 1236 [5].

Мета. Привести сучасний досвід професорсько-викладацького складу кафедри медичного та фармацевтичного права, загальної і клінічної фармації 
Харківської медичної академії післядипломної освіти (ХМАПО) щодо проведення навчального процесу в період карантину, спричиненого гострою респіраторною хворобою COVID-19 внаслідок коронавірусу SARS-CoV-2, на прикладі циклів підвищення кваліфікації фахівців медицини та фармації 3 використанням технологій дистанційного навчання.

Нові карантинні обмеження

На території України з 23.09.21 р. запроваджено «ЖОВТИЙ» рівень епідемічної небезпеки

Що він передбачає?

- Навчальні заклади працюють, якщо не менше $80 \%$ працівників такого закладу мають принаймні одне щеплення проти COVID-19

- $\quad$ Громадські заклади (кафе, театри, концертні майданчики, кінотеатри тощо) працюють без обмежень «жовтого» рівня, якщо $80 \%$ працівників та всі відвідувачі закладу мають принаймні 1 щеплення або чинний (72 години) негативний тест на коронавірус

- Кожен власник закладу сам обирає формат роботи: 3 перевіркою COVID-сертифікатів у відвідувачів і без обмежень «жовтого» рівня, або 3 обмеженнями i без перевірок таких документів
При «жовтому» рівні діятимуть такі карантинні обмеження:

- Заборонено проводити масові заходи за участю понад однієї особи на 4 кв.м. площі території або наповненістю залів понад 2/3 місць у кожному окремому залі

- Не більше 4 осіб за столиком в закладі громадського харчування, а відстань між столами - мінімум 1,5 метри

- Кінотеатри та інші заклади культури працюватимуть із наповненістю залів менше за дві третини місць або 50\% місць у кожному окремому залі

- Спортивні зали та фітнес-центри працюватимуть лише у разі обмеження кількості відвідувачів 3 розрахунку одна особа на 10 кв.м. площі тощо

\begin{tabular}{|ll}
\hline \multicolumn{1}{|c|}{ COVID-сертифікати для відвідування громадських закладів } \\
$\checkmark$ & внутрішній COVID-сертифікат в Дія («жовтий» або «зелений») \\
$\checkmark$ & міжнародне свідоцтво про вакцинацію \\
$\checkmark$ & чинна (72 години) довідка про негативний результат тесту на коронавірус \\
$\checkmark$ & довідка 063-О (картка профщелень)
\end{tabular}

Рис. 1. «Жовтий» рівень карантинних обмежень

Матеріали та методи дослідження. Опрацьовано міжнародні акти, законодавчі та нормативно-правові документи України (більше 170), а також накази і розпорядження в.о. ректора ХМАПО, які безпосередньо стосувалися організації роботи професорсько-викладацького складу академії у період карантину, спричиненого гострою респіраторною хворобою COVID-19, 
внаслідок коронавірусу SARS-CoV-2. Приведено особливості дистанційного викладання в системі «moodle» на циклі ТУ «Медичне та фармацевтичне право в діяльності закладів охорони здоров'я». Використано методи нормативноправового, документального, порівняльного, системного та графічного аналізу. Для дистанційного навчання використано програму «Moodle» та «Вайбер». Moodle (акронім від Modular Object-Oriented Dynamic Learning Environment модульне об'єктно-орієнтоване динамічне навчальне середовище) - навчальна платформа призначена для об'єднання педагогів, адміністраторів i учнів (студентів) в одну надійну, безпечну та інтегровану систему для створення персоналізованого навчального середовища. Moodle - це безкоштовна, відкрита (Open Source) система управління навчанням. Viber (укр. Вайбер) VoIP-додаток для дзвінків і обміну повідомленнями. Застосунок підв'язується до номера мобільного телефона, але не використовує мобільну мережу. Для здійснення дзвінків і обміну повідомленнями програма потребує інтернетз'єднання. У месенджері можна створювати чат-боти та спільноти та здійснювати платежі.

Результати дослідження та їх обговорення. Відповідно до пункту 25 резолюції, прийнятої Генеральною Асамблеєю 25.09.2015 року «Перетворення нашого світу: Порядок денний у сфері сталого розвитку до 2030 року» акцентовано увагу про те, що: «..ми зобов'язуємося забезпечити якісну інклюзивну та рівноправну освіту на всіх рівнях, як-от: дошкільного виховання, початкова, середня, вища освіта, а також професійно-технічна підготовка. Усі люди, незалежно від статі, віку, раси та етнічного походження, а також особи $з$ інвалідністю, мігранти, представники корінних народів, діти та молоді люди, особливо ті, що перебувають у вразливій ситуації, повинні мати можливість здобувати освіту протягом усього життя, що допоможе їм набувати знань і навичок, необхідних для використання наявних можливостей та повноцінної участі у житті суспільства. Ми намагатимемося створити для дітей та молоді середовище, сприятливе для повної реалізації ними своїх прав і можливостей, що допоможе нашим країнам скористатися демографічним дивідендом, зокрема завдяки безпеці шкіл та згуртованості громад і сімей...» [13].

Чому своєчасно потрібно підвищувати кваліфікацію лікарям та провізорам саме на нашій кафедрі? Відповідь проста, щоб:

- проводити навчання через все життя у відповідності до п. 2. статті 26 Загальна декларація прав людини, що прийнята і проголошена в резолюції 217 А (III) Генеральної Асамблеї від 10.12.1948 р.., тобто «... Освіта повинна бути спрямована на повний розвиток людської особи і збільшення поваги до прав людини i основних свобод. Освіта повинна сприяти взаєморозумінню, терпимості і дружбі між усіма народами, расовими і релігійними групами $\mathrm{i}$ повинна сприяти діяльності ООН з підтримання миру...» [14];

- підняти рівень компетентності, тобто здатність особи успішно соціалізуватися, навчатися, провадити професійну діяльність, яка виникає на основі динамічної комбінації знань, умінь, навичок, способів мислення, поглядів, цінностей, інших особистих якостей (п. 13, статті 1 «Основні терміни 
та їх визначення», розділу 1 «Загальні положення» Закону України «Про вищу освіту») [15];

- попередити причини та умови, що спричиняють дисциплінарну, адміністративну або кримінальну відповідальність [16-19].

Далі приведено приклади із судово-фармацевтичної практики щодо кримінальних правопорушень, скоєних лікарями в умова карантину.

Приклад 1. Суддею Васильківського міськрайсуду Київської області завершено слухання кримінальної справи щодо медичного працівника, якому було оголошено обвинувачення за ч. 1 статті 368 КК України, тобто лікар за грошову винагороду намагався сфальсифікувати документ, щоб надати призовникові відстрочку від призову до ЗС України [20]. Під час судового розгляду справи встановлено, що 23.11.2020 року лікар-хірург КНП «Васильківської ЦРЛ», який входив до складу спеціалістів районної медичної призовної комісії, одержав від призовника неправомірну вигоду розміром 1000 у.о. США за написання ним висновку з неправдивим діагнозом. На підставі цього діагнозу районна призовна комісія повинна була б ухвалити рішення про надання призовникові відстрочки від призову на строкову військову службу. Суд визнав лікаря-обвинуваченого за ч. 1 статті 368 КК України, винним у вчиненому злочині (прийняття пропозиції, обіцянки або одержання неправомірної вигоди службовою особою). Однак, взявши до уваги пом'якшувальні обставини (вину визнав та щиро розкаявся у скоєному злочині; активно сприяв розкриттю кримінального правопорушення; має на утриманні дитину з інвалідністю; чинений злочин скоїв уперше), затвердив укладену 20.01.2021 року між заступником начальника відділу Спеціалізованої прокуратури у військовій та оборонній сфері Центрального регіону гр. П. і обвинуваченим лікарем гр. А. угоду щодо визнання винуватості та призначив покарання у вигляді штрафу розміром 1700 неоподатковуваних мінімумів доходів громадян, що становить 28900 грн 3 позбавленням права здійснювати повноваження лікаря у складі медичних комісій (військово-лікарських комісій, призовних комісій) військових комісаріатів строком один рік.

Приклад 2. Київською міською прокуратурою повідомлено про підозру 33-річному лікарю-стоматологу у вчиненні замаху на вбивство, розбійних нападах, крадіжці, шахрайстві у особливо великих розмірах та погрозі насильством щодо працівника правоохоронного органу (ч. 2 ст. 15 ч. 1 ст. 115, ч. 3 ст. 185, ч. 3 ст. 187, ч. 2 ст. 190, ч. 1 ст. 345 КК України) [21-24]. Під час досудового розслідування встановлено, що з травня 2019 року по вересень 2020 p. 33-лікар, який займався стоматологічною практикою у м. Києв, вводив пацієнтів в оману, повідомляючи їм хибну інформацію щодо необхідного обсягу медичного лікування. Внаслідок злочинних дій відносно пацієнтів, лікар-стоматолог заволодів близько 400 тисячами гривень. Разом 3 тим, у березні 2020 р. лікар-стоматолог під приводом необхідності здійснення медичних процедур проник до житла однієї з пацієнток та викрав банківську картку, з якої в подальшому зняв 78 тисяч гривень. Крім того, у червні 2020 р. лікар-стоматолог під приводом супроводження однієї з пацієнток додому 
застосував сильнодіючий препарат «клофелін». Від фармакологічної дії препарату потерпіла втратила контроль над своїми діями. Надалі, користуючись ii напівпритомним станом, лікар-стоматолог заволодів грошовими коштами та матеріальними цінностями потерпілої пацієнтки на загальну суму 63 тисячі гривень. Крім цього, лікар-стоматолог підозрюється у замаху на вбивство 70-річної громадянки шляхом під'єднання електричних дротів, які заздалегідь мав при собі, до електричного живлення напругою 220 Вт в електричному щитку, що розташований поряд 3 квартирою проживання потерпілої. Підозрюваному лікарю-стоматологу, обрано запобіжний захід у вигляді тримання під вартою. Під час засідання з обрання запобіжного заходу підозрюваний здійснював погрози на адресу прокурора, у зв'язку з чим йому додатково інкриміновано ч. 1 ст. 345 КК України. Також на теперішній час на розгляді судів м. Києва перебувають ще два кримінальні провадження відносно цього лікаря-стоматолога за фактами вчинення інших тяжких злочинів: у Дарницькому районному суді за ч. 1 ст. 187, ч. 3 ст. 185 КК України; у Броварському міськрайонному суді Київської області за ч. 3 ст. 185 КК України. За участю прокурора Київської міської прокуратури у Голосіївському районному суді м. Києва відбулося підготовче судове засідання у справі відносно столичного лікаря-стоматолога обвинуваченого у вчиненні кримінальних правопорушень. Суддею Голосіївського районного суду міста Києва під час підготовчого засідання від лікаря-стоматолога, обвинуваченого у скоєні тяжких злочинів, отримано клопотання про розгляд справи у суді за участю присяжних, у зв'язку із чим колегія судів ухвалила та призначила судовий розгляд справи судом присяжних у відкритому судовому засіданні Голосіївського районного суду міста Києва.

Вирішення невизначеностей є надважливим завданням, особливо під час кризи, i значно якісніший рівень комунікації як 3 боку керівництва університету, так і всередині бізнес шкіл сприяв зменшенню прірви між керівництвом та колегами, а однією 3 найприємніших переваг адаптації до COVID-19 стала успішність проведення онлайн-засідань у Teams aбo Zoom, які дозволяють працювати у форматі питання - відповіді, під час яких співробітники можуть отримати вичерпні відповіді щодо дії університетів під час кризи. Зв’язок зі студентами був дещо складнішим через їхні особистісні способи навчання та необхідність надавати їм постійну підтримку та консультації. Загалом, COVID-19 призвів до значних інновацій в Школі Менеджменту Університету Бат (Великобританія) та Університеті менеджменту (Сінгапур), які пов'язані з процесами та термінами управління навчальним процесом. Ці нововведення значно підвищили рівень гнучкості, спритності та можливостей для інновацій курсів та програм, що існують в цих закладах вищої освіти [25].

Дистанційне навчання в умовах сьогодення стає невід'ємним елементом нашого життя, зокрема й вищої освіти. Констатовано, що на вимогу сьогодення доступ до вищої освіти варто розширити, що передбачає вдосконалення навчального середовища, створення відповідних економічних умов, щоб 
студенти могли користуватися навчальними можливостями на всіх рівнях. Але водночас, ураховуючи можливі негативні наслідки зловживання віртуальною реальністю, педагогічна наука все ще обмежує застосування таких інформаційно-комунікативних технологій. Не викликає сумніву той факт, що на вимогу сьогодення доступ до вищої освіти варто розширити шляхом удосконалення навчального середовища, створення відповідних економічних умов, щоб студенти могли користуватися навчальними можливостями на всіх рівнях. Проте разом із тим доцільно враховувати можливі негативні наслідки зловживання віртуальною реальністю. Указано, що за підтримки навчального закладу саме викладач має встановлювати межі, створювати програми, розробляти завдання, організовувати спілкування в мережі, консультувати на всіх етапах діяльності й, урешті, оцінювати навчальні досягнення студентів. Студент має бути активним учасником навчального процесу [26].

Методичні рекомендації щодо реалізації педагогічних умов впровадження дистанційного навчання в освітній процес закладу вищої освіти зі специфічними умовами навчання, які здійснюють підготовку поліцейських, повинні складатися у відповідності з наступною структурою: - рекомендації для викладача 3 організації інформаційно-технологічного освітнього середовища (вибір стилю взаємодії суб'єктів освітнього процесу всередині середовища, співвідношення традиційних та інноваційних методів, засобів і форм навчання); - рекомендації для викладача по розробці дидактичного забезпечення дистанційного навчання (зміст електронних освітніх ресурсів, баз даних тощо.); - рекомендації щодо підвищення інформаційної компетентності викладачів закладу вищої освіти, зокрема вміння вільно володіти платформами Skype, Moodle, Zoom, Skype, Viber, Telegram, Messenger та Prometheus, 3 метою реалізації дистанційного навчання [27]. Автори також вважають доволі зручною платформу Microsoft Teams.

В окремих джерелах літератури констатовано, що в умовах пандемії COVID-19 більше третини студентів (учасників дослідження) визначались низьким рівнем самопочуття, активності, настрою, переживаючи при цьому підвищену тривожність, агресивність; їм була притаманна ригідність та стан фрустрації. З'ясовано, що переважна більшість здобувачів вищої освіти не вважають дистанційну форму навчання ефективною для себе, оскільки їм бракує ефективної комунікації, збільшується їх навантаження, змінюється режим, погіршується самопочуття через втому та одноманітність. Суб'єктивна самооцінка емоційних, фізичних та когнітивних змін продемонструвала підвищення рівня емоційного напруження, тривоги, відчуття провини, розвиток відчуття соціального відчуження, брак спілкування, постійні зміни настрою, труднощі з концентрацією уваги, та самоорганізацією, погіршення загального фізичного самопочуття через постійну втому, проблеми 3 травленням, змінами апетиту, зниження якості сну. Виявлено кореляційну пряму залежність між рівнями тривожності, фрустрації, ригідності та агресивності; протилежну залежність - між рівнями самопочуття та активності і фізичних та когнітивних змін [28-30]. 
Емпірично визначено, що у тих, хто спілкується у віртуальному просторі до 4 годин у день зі збільшенням цього часу підвищується автономність та компетентність. А у тих, хто спілкується у соціальних мережах більше 4 годин на день зі збільшенням часу перебування знижується компетентність, позитивні стосунки та стають нечіткими життєві цілі. Тривалість перебування у соціальних мережах впливає на психологічне благополуччя особистості. Але ми не можемо зробити однозначне припущення, бо кореляційний аналіз нам говорить про наявність зв'язку, а не про причинність. Перспективами дослідження вбачаємо вироблення корекційно розвивальних заходів допомоги особистості з оптимізації психологічного благополуччя та зниження залежності від соціальних мереж [31].

Дистанційне навчання, як невід'ємний компонент науково-педагогічного процесу набуває свого активного розвитку за часів пандемії коронавірусу. Сьогодення дає виклик викладачам для освоєння новітніх технологій, для виходу на новий рівень освітнього процесу. Звичайно, будь-які зміни викликають психологічних дискомфорт, а тим більше, форс-мажорні обставини. Тому, в цей нелегкий час для нашої країни, вивчення, аналіз та допомога в структуризації, нормалізації процесу дистанційного навчання $\epsilon$ нагальним питанням для кожного громадянина. Перспективи дослідження вбачаю в подальшому вивченні впливу дистанційного навчання на формування фахівців, аналізі успішності студентів та слухачів у порівняльному контексті, вивченні емоційного стану учасників навчального процесу [32].

Отже, пандемія коронавірусу COVID-19 безжально вносить корективи у функціонування вітчизняних культурних та навчальних практик i визначає вектори їх розвитку. Проте, у впливі всесвітньої епідемії на культурні, навчальні та креативні індустрії, можливо виокремити й позитивні наслідки: стимуляцію до пошуку оригінальних рішень і альтернатив, що допомагають знаходити актуальні способи вирішення проблем у сфері навчання задля збереження та популяризації освітнього продукту та адаптацію до нових реалій через створення інноваційних методів проведення масових подій [33].

Єдина система управління та зберігання контенту дозволяє гнучко управляти правами доступу до контенту - наприклад, надати доступ до певної лекції чи презентації, розміщеної у хмарних сервісах, тільки для певної групи людей, не змішуючи до купи матеріали всіх викладачів курсу, які мають окремі групи та траекторію навчання. Крім того зручно робити еmail-розсилки та планувати проведення заходів у спільних календарях, які також можуть синхронізуватися із відповідними віджетами у Moodle [34].

Для управління процесом дистанційного (змішаного) навчання слід використовувати окрему програмну систему (наприклад, Moodle). При обранні такої системи слід звертати увагу не тільки на вартість але й на те, чи легко до системи можуть бути інтегровані інші веб-сервіси. Система Moodle дуже легко інтегрується 3 багатьма зовнішніми системами: Google, Facebook, Virtual Programming Lab та інші. Залучення сервісів Google Suite for Education дозволяє не тільки легко аутентифікувати користувачів, але і зберігати великі файли 
(аудіо, відео, презентації) у необмеженому хмарному сховищі Google. Дуже зручно використовувати і нестандартні сервіси Google, такі як "Студія даних" 33 (https://datastudio.google.com), що дозволяє проводити повний аналіз даних на зовнішньому сервісі. Також дуже зручно використовувати зовнішні системи створення інтерактивних веб-сторінок (наприклад, https://h5p.org/), для вбудови y Moodle [35].

Однією з основних завдань сучасної освіти є підготування фахівця, який буде максимально вільно орієнтуватися у світовому інформаційному просторі. Має навички щодо зберігання, оброблення та пошуку важливої інформації. Дистанційне навчання покликане допомогти в глобальному освітньому просторі, але без професійних фахівців, які будуть завідувати дистанційними процесами нічого не вдасться. Актуальним напрямом подальшої роботи $є$ аналіз стану дистанційної освіти в Україні в теорії та практиці ВНЗ, уточненні сутності базових понять, теоретичне обгрунтування психолого-педагогічних принципів розробки та використання частин дистанційної освіти [36].

Підвищення рівня доступності слухачів під час інтерактивного спілкування має позитивне значення для успішності навчання під час карантину. Закон України «Про освіту» гарантує загальний доступ до освіти [16].

Організація процесу навчання в ХМАПО в умовах карантину базується на наступних нормативно-правових актах, а саме:

- $\quad$ наказом в.о. ректора ХМАПО від 12.03.2020 р. №142-з було оголошено карантин в академії;

- $\quad$ наказом в.о. ректора ХМАПО від 12.03.2020 р. №144-3 «Про особливості організації навчального процесу на циклах спеціалізації та підвищення кваліфікації лікарів під час карантину» було заборонено проведення навчальних занять 3 кількістю понад 200 осіб і забезпечено застосування дистанційних навчальних технологій;

- $\quad$ наказ Міністерства освіти і науки України від 16.03.2020 р №406 «Про організаційні заходи для запобігання поширенню коронавірусу COVID-19». 18.03.2020 р. наказом в.о. ректора ХМАПО №152-3 «Про додаткові заходи 3 організації навчального процесу в зв'язку з карантином» було призупинено до 03.04. 2020 р. або до особливого розпорядження Кабінету Міністрів України відвідування навчальних занять усіма здобувачами післядипломної освіти для осіб з вищою освітою та здобувачами вищої освіти всіх рівнів;

- $\quad$ наказом в.о. ректора ХМАПО від 27.04.2020 р. № 188-з було посилено організаційні та протиепідемічні заходи в академії на період дії карантину.

В подальшому наказами в.о. ректора ХМАПО було продовжено дію карантину (наказ ХМАПО від 06.05.2020 p. №198-3; наказ ХМАПО від 22.05.2020 p. №212-3; наказ ХМАПО від 19.06.2020 p. № 241-з; наказ ХМАПО від 15.10.2020 р. № 486-3; наказ ХМАПО від 26.04.2021 р. №234-3; наказ ХМАПО від 17.08.2021 р. № 451-3).

Розпорядженням в.о. ректора ХМАПО від 01.06 .2020 р. № 22 «Про організацію протиепідемічних заходів при проведенні атестації здобувачів 
освіти за спеціальностями галузі знань «22 Охорона здоров'я» у період карантину у зв'язку з поширенням коронавірусної хвороби (COVID-19)» було детально описано процедуру проведення іспиту «Крок 3».

Наказом в.о. ректора ХМАПО від 14.08.2020 р. №325-з було затверджено Тимчасові рекомендації в ХМАПО щодо організації протиепідемічних заходів в період карантину в зв'язку з поширенням коронавірусної хвороби (COVID-19).

Наказом в.о. ректора ХМАПО від 17.08.2020 р. №326-з організовано протиепідемічні заходи у гуртожитках академії.

Наказом в.о. ректора ХМАПО від 02.10.2020 р. № 465-з посилено організаційні та протиепідемічні заходи в ХМАПО на період дії карантину щодо COVID-19.

Також було оптимізовано заходи на період дії карантину (наказ в.о. ректора ХМАПО від 06.04.2020 p. № 174-3) і організовано дистанційне навчання на час дії карантину, спричиненого коронавірусом COVID-19 (розпорядження в.о. ректора ХМАПО від 07.04.2020 р. №16).

Було видано розпорядження в.о. ректора від 26.10 .2020 р. №46 «Про проведення атестації на визначення знань та практичних навичок 3 присвоєнням (підтвердженням) звання «лікар-спеціаліст» дистанційно».

3 метою запобігання поширенню на території України гострої респіраторної хвороби COVID-19, спричиненої коронавірусом SARS-CoV-2, в ХМАПО було організовано навчальний процес і проведення всіх масових заходів у дистанційному режимі (наказ в.о. ректора від 24.12.2020 р. №628-3). Так, 12.03.2021 p. розпорядженням в.о. ректора ХМАПО № 11 було оголошено надати списки із числа професорсько-викладацького складу клінічних кафедр для проведення щеплень проти коронавірусної інфекції.

Наказом в.о. ректора ХМАПО від 23.02.2021 р. №115-з організовано роботу академії відповідно до Постанови Кабінету Міністрів України від 17.02.2021 p. №104 «Про внесення змін до деяких актів Кабінету Міністрів України». Було оновлено склад оперативної групи по боротьбі і профілактиці короравірусу COVID-19 (наказ в.о. ректора ХМАПО від 23.03.2021 р. №164-з).

Наказом в.о. ректора ХМАПО 12.04.2021 р. №210-з було організовано роботу академії в умовах «червоного» рівня епідеміологічної небезпеки на території Харківської області. Від 12.05.2021 р. затверджено протиепідемічні заходи в ХМАПО (наказ в.о. ректора 12.04.2021 р. № 260-3).

У якості прикладу дистанційного навчання приведено скріншоти навчально-методичних матеріалів на циклі ТУ «Медичне та фармацевтичне право в діяльності закладів охорони здоров'я» (Рис. 2-15). Для дистанційного навчання використовували програму «Moodle». Слухачі після електронної реєстрації отримували логіни та паролі для індивідуального входу на платформу і доступу до матеріалів для навчання. 


\section{ТУ 'Медичне та фармацевтичне право в діяльності закладів охорони здоров'я"}

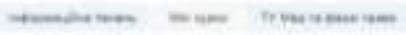

Тематичне удосконапення "Медичне та фармацеатичне право в дівпьності аөкладів охорони здоров'я"

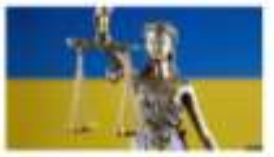

Dura lex med lex. Banow cysopveh, ane ue saxom

Jus est ars boni et aequi. npano $\mathrm{e}$ nayka noбporo ta pianoro.

$$
\begin{aligned}
& \text { Rirsenes ncis isospe-sopeserin }
\end{aligned}
$$

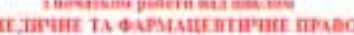

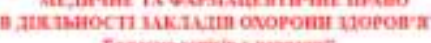

Рис. 2. Привітання слухачів циклу ТУ «Медичне та фармацевтичне право в діяльності закладів охорони здоров'я»

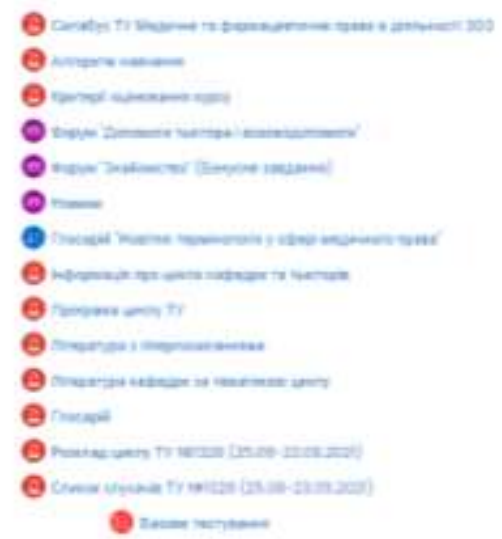

Рис. 3. Основна інформація циклу ТУ «Медичне та фармацевтичне право в діяльності закладів охорони здоров'я»

1 тиждень

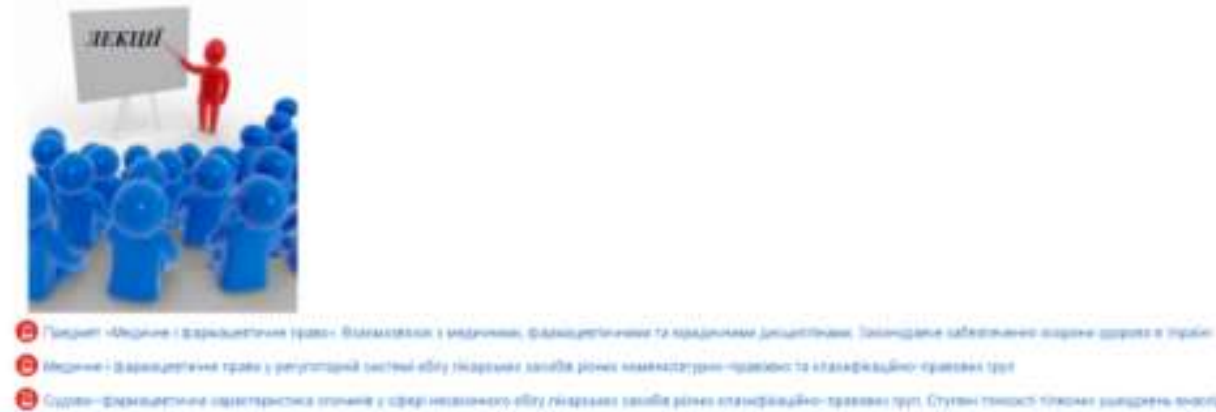

Рис. 4. Матеріали лекцій до циклу ТУ «Медичне та фармацевтичне право в діяльності закладів охорони здоров'я» на першому тижні навчання 


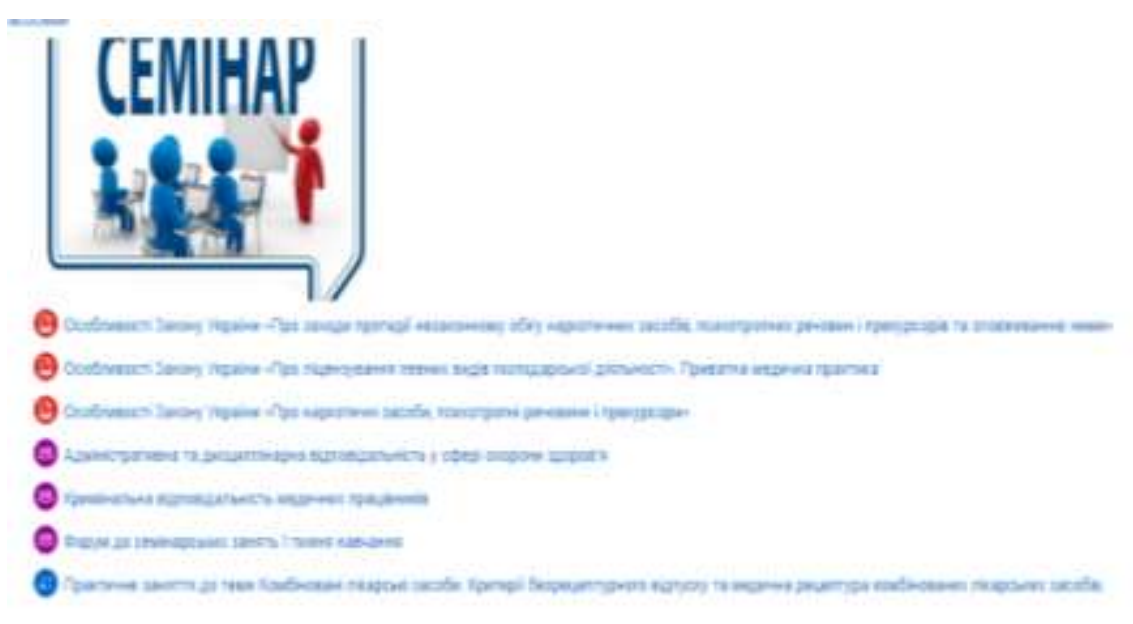

Рис. 5. Матеріали семінарських занять до циклу ТУ «Медичне та фармацевтичне право в діяльності закладів охорони здоров'я» на першому тижні навчання

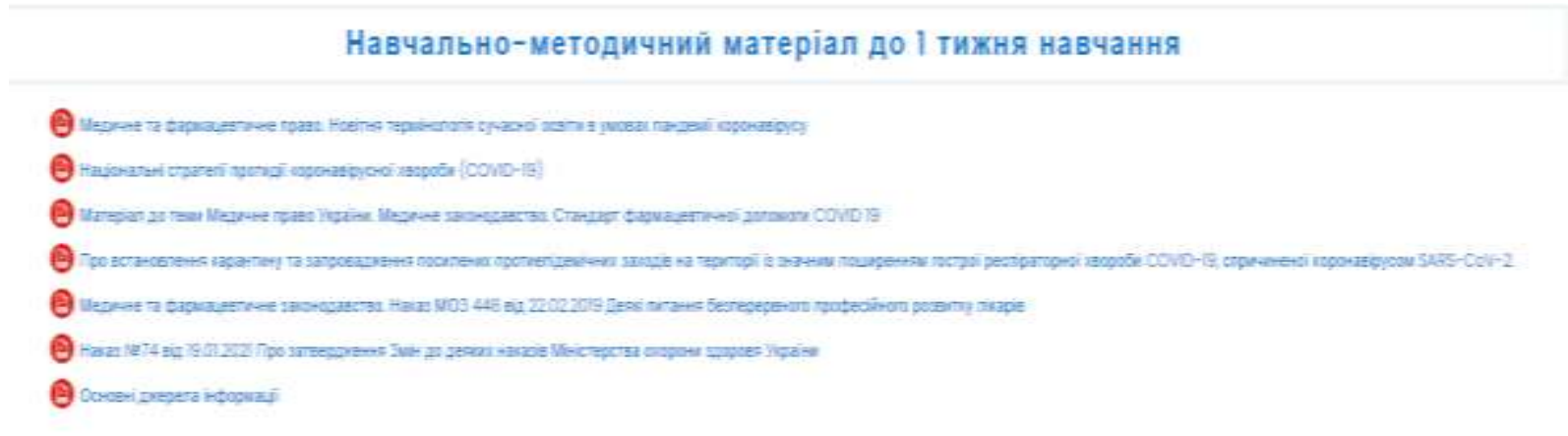

Рис. 6. Навчально-методичний матеріал до 1 тижня навчання на циклі ТУ «Медичне та фармацевтичне право в діяльності закладів охорони здоров’я»

$$
2 \text { тиждень }
$$

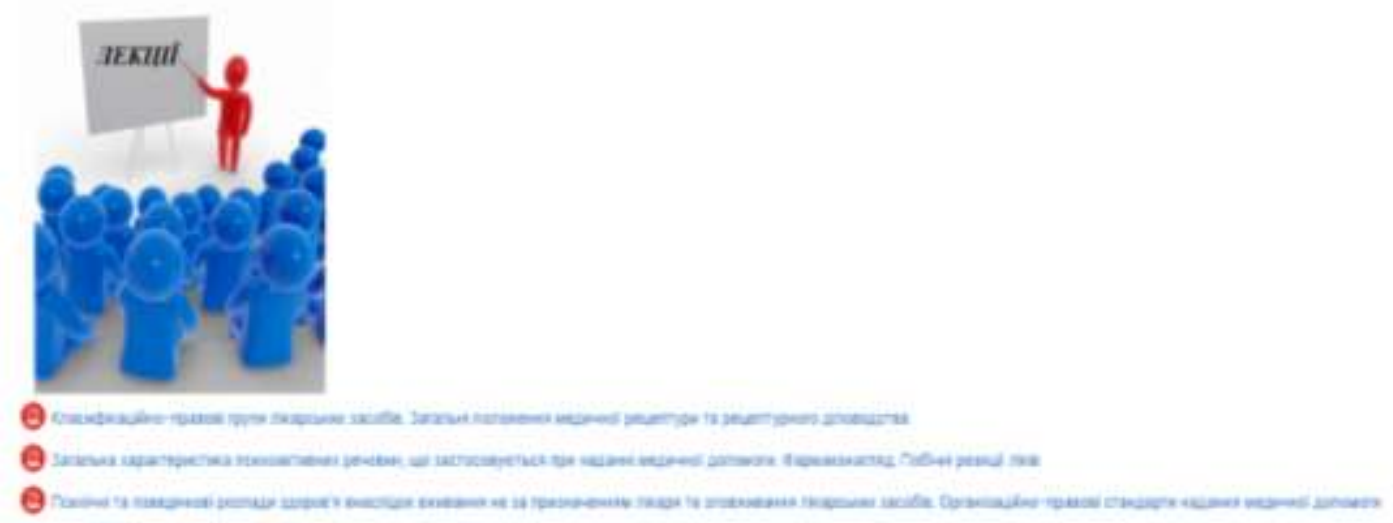

Рис. 7. Матеріали лекцій до циклу ТУ «Медичне та фармацевтичне право в діяльності закладів охорони здоров'я» на другому тижні навчання 


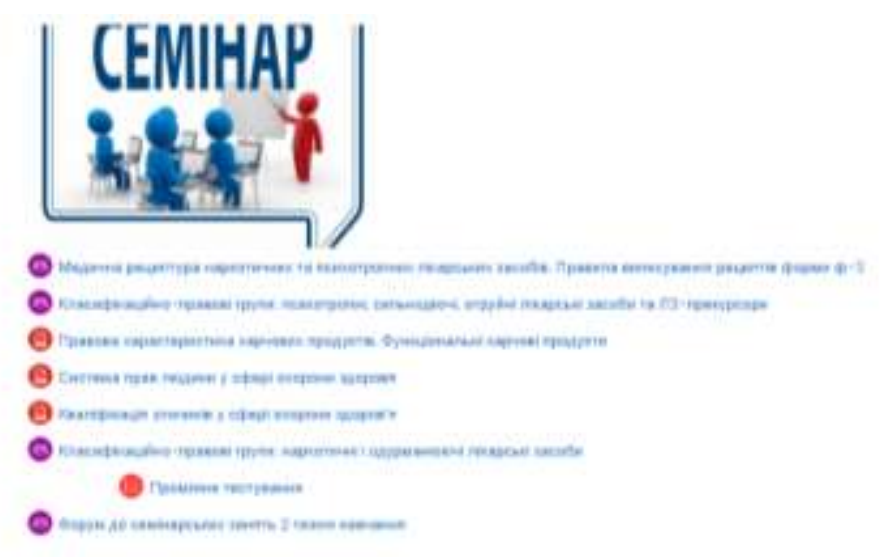

Рис. 8. Матеріали семінарських занять до циклу ТУ «Медичне та фармацевтичне право в діяльності закладів охорони здоров'я» на другому тижні навчання

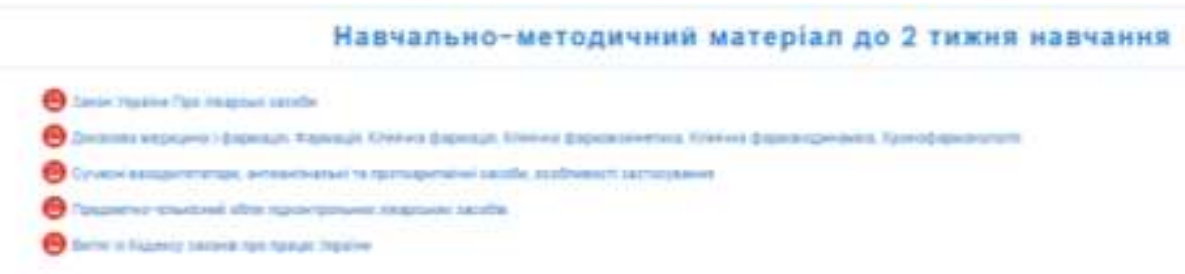

Рис. 9. Навчально-методичний матеріал до 2 тижня навчання на циклі ТУ «Медичне та фармацевтичне право в діяльності закладів охорони здоров'я»

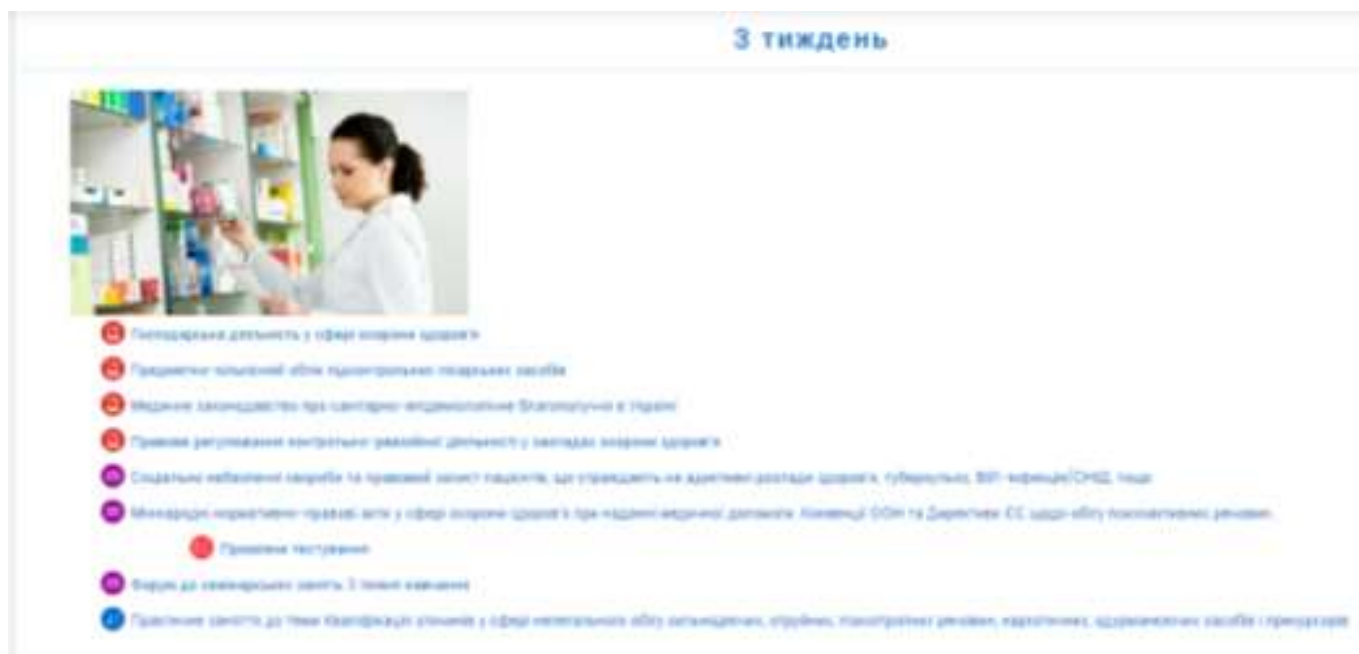

Рис. 10. Навчальні матеріали до 3 тижня навчання на циклі ТУ «Медичне та фармацевтичне право в діяльності закладів охорони здоров'я»

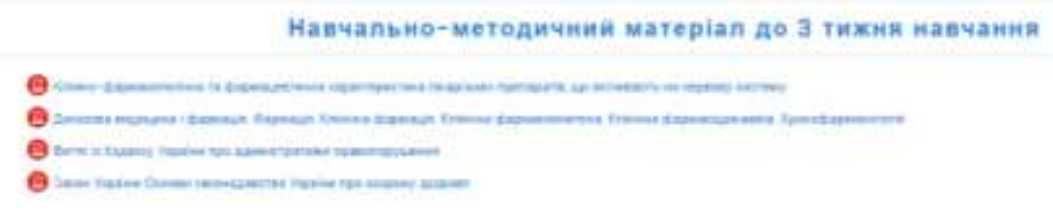

Рис. 11. Навчально-методичний матеріал до 3 тижня навчання на циклі ТУ «Медичне та фармацевтичне право в діяльності закладів охорони здоров'я» 


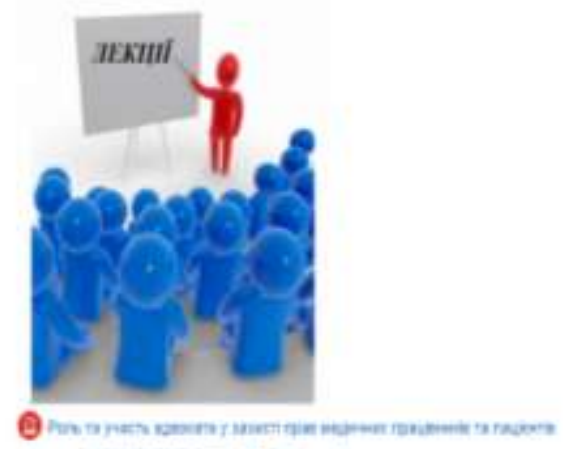

Рис. 12. Матеріали лекцій до циклу ТУ «Медичне та фармацевтичне право в діяльності закладів охорони здоров'я» на четвертому тижні навчання

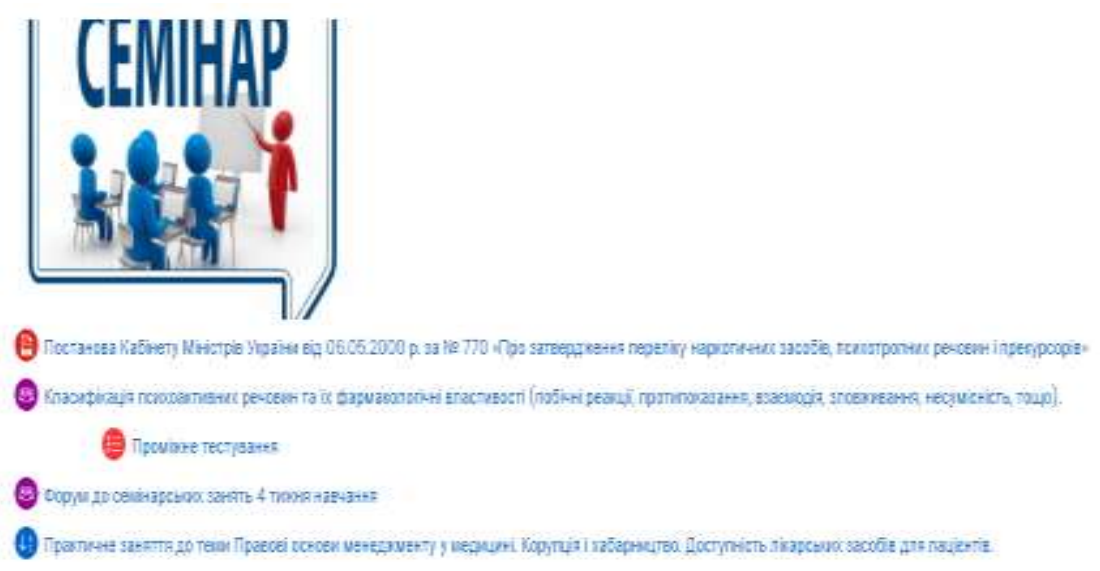

Рис. 13. Матеріали семінарських занять до циклу ТУ «Медичне та фармацевтичне право в діяльності закладів охорони здоров'я» на другому тижні навчання

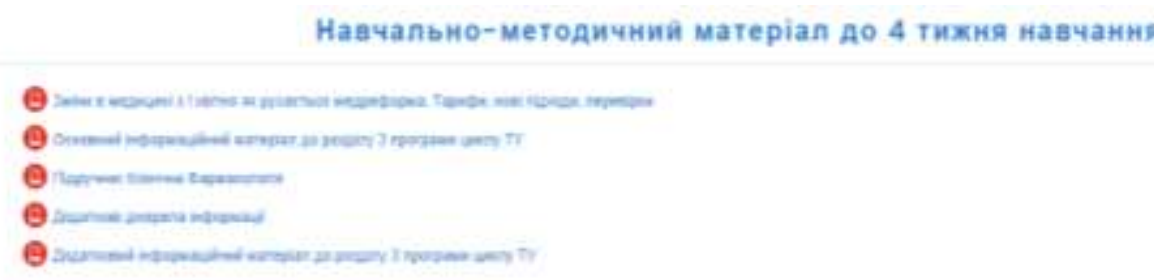

Завдакня для самостіиної роботи слухача

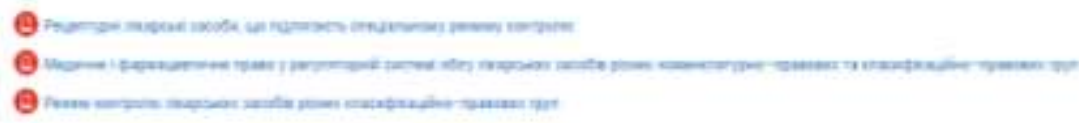

Дадаткові програми

$\Theta$

Q

Рис. 14. Навчально-методичний матеріал, завдання для самостійної роботи слухача та додаткові програми до 4 тижня навчання на циклі ТУ «Медичне та фармацевтичне право в діяльності закладів охорони здоров'я» 
Рис. 15. Заключний тестовий контроль для завершення навчання на циклі ТУ «Медичне та фармацевтичне право в діяльності закладів охорони здоров'я»

Робота слухачів на платформі контролювалася викладачами кафедри медичного та фармацевтичного права, загальної і клінічної фармації. Після завершення навчання слухачі заповнювали анкету, де 95\% вказали, що навчання було якісним, доступним, інформативним тощо.

Також слід вказати, що кафедрою для провізорів проводяться курси за спеціальностями:

- «Загальна фармація» (цикл спеціалізації (інтернатури), передатестаційний цикл, стажування, тематичного удосконалення);

- 《Клінічна фармація» (цикл спеціалізації (інтернатури), передатестаційний цикл, тематичного удосконалення);

- «Організація i управління фармацією» (цикл спеціалізації, передатестаційний цикл, стажування, тематичного удосконалення);

- «Аналітично-контрольна фармація» (цикл тематичного удосконалення, спеціалізації, передатестаційний цикл).

Для лікарів (лікувального, педіатричного i стоматологічного профілю) проводяться курси тематичного удосконалення:

- Медичне та фармацевтичне право в діяльності закладів охорони здоров'я;

- Основи медичного та фармацевтичного права в діяльності лікаря загальної практики - сімейної медицини;

- Медичне та фармацевтичне право у стоматології;

- Організаційно-правові аспекти ліцензування обігу лікарських засобів різних класифікаційно-правових груп у закладах охорони здоров'я;

- Організація вхідного контролю якості лікарських засобів у закладах охорони здоров'я на основі медичного та фармацевтичного права;

- Медичне право в діяльності закладів охорони здоров'я;

- Сучасні тенденції медичного та фармацевтичного права в діяльності закладів охорони здоров'я;

- Особливості діяльності закладів охорони здоров'я під час карантину, спричиненого коронавірусом SARS-CoV-2

Для провізорів проводяться курси тематичного удосконалення:

- Організація і управління фармацією на засадах фармацевтичного права;

- Загальна фармація на засадах фармацевтичного права;

- Фармацевтичне і медичне право в організації післядипломної освіти керівників провізорів-інтернів; 
- «Оптимізація діяльності закладів охорони здоров’я на засадах фармацевтичного права».

Дослідження законодавчих змін у медичній і освітній сфері діяльності, що сталися внаслідок встановлення карантину та запровадження обмежувальних протиепідемічних заходів з метою запобігання поширенню на території України захворюваності серед всіх верств населення, а саме гострої респіраторної хвороби COVID-19 на принципах медичного та фармацевтичного права було проведено у співпраці $3 \mathrm{x}$ вишів та описано у статті вітчизняних авторів [37].

Висновки. Узагальнено досвід професорсько-викладацького складу кафедри медичного та фармацевтичного права, загальної і клінічної фармації ХМАПО щодо проведення навчального процесу в період карантину, спричиненого гострою респіраторною хворобою COVID-19 внаслідок коронавірусу SARS-CoV-2, на прикладі циклів підвищення кваліфікації фахівців медицини та фармації 3 використанням технологій дистанційного навчання. Зазначено, що в ХМАПО дотримуються протиепідемічних заходів 3 метою запобігання поширенню в освітньому процесі гострої респіраторної хвороби COVID-19. Кафедра медичного та фармацевтичного права, загальної і клінічної фармації успішно проводить цикли для лікарів і провізорів 3 використанням технологій дистанційного навчання. Підкреслено про позитивні відгуки від лікарів та провізорів про організацію кафедрою медичного та фармацевтичного права, загальної і клінічної фармації ХМАПО дистанційного навчання (95\% слухачів задоволені пройденими курсами підвищення кваліфікаціі).

Конфлікт інтересів. Автори стверджують, що між ними немає конфлікту інтересів щодо цієї публікації.

\section{Лiтература.}

1. Postanova Kabinetu Ministriv Ukrainy vid 22.09.2021 r. №981 "Pro vnesennia zmin do deiakykh aktiv Kabinetu Ministriv Ukrainy". URL: https://zakon.rada.gov.ua/laws/show/981-2021-\%D0\%BF.

2. Businesses in the "yellow zone" can choose either to work with restrictions or without it but with COVID certificates. Denys Shmyhal. Communications Department of the Secretariat of the Cabinet of Ministers of Ukraine. 22.09.2021. URL: https://www.kmu.gov.ua/en/news/u-zhovtij-zonipidpriyemci-mozhut-obrati-pracyuvati-z-obmezhennyami-abo-bez-obmezhenale-z-kovid-sertifikatami-denis-shmigal.

3. Rozporiadzhennia Kabinetu Ministriv Ukrainy vid 25.03.2020 r. №338 “Pro perevedennia yedynoi derzhavnoi systemy tsyvilnoho zakhystu $u$ rezhym nadzvychainoi sytuatsii". URL: https://zakon.rada.gov.ua/laws/show/338-2020$\% \mathrm{D} 1 \% 80$.

4. Postanova Kabinetu Ministriv Ukrainy vid 09.12.2020 r. №1236 “Pro vstanovlennia karantynu ta zaprovadzhennia obmezhuvalnykh protyepidemichnykh zakhodiv $\mathrm{z}$ metoiu zapobihannia poshyrenniu na terytorii Ukrainy hostroi 
respiratornoi khvoroby COVID-19, sprychynenoi koronavirusom SARS-CoV-2". URL: $\quad$ https://www.kmu.gov.ua/npas/pro-vstanovlennya-karantinu-tazaprovadzhennya-obmezhuvalnih-protiepidemichnih-zahodiv-1236-091220.

5. Postanova Kabinetu Ministriv Ukrainy vid 9 hrudnia 2020 r. №1236 «Pro vstanovlennia karantynu ta zaprovadzhennia obmezhuvalnykh protyepidemichnykh zakhodiv $\mathrm{z}$ metoiu zapobihannia poshyrenniu na terytorii Ukrainy hostroi respiratornoi khvoroby COVID-19, sprychynenoi koronavirusom SARS-CoV-2». URL: https://zakon.rada.gov.ua/laws/show/1236-2020-\%D0\%BF.

6. Shapovalov V.V., Shapovalova V.O., Shapovalov V.V. et al. Medychne ta farmatsevtychne pravo: navch. posib. dlia dodyplomnoi ta pisliadyplomnoi formy navchannia. Seriia «Medychne ta farmatsevtychne pravo». 4-e vyd. zi zminamy ta dopovnenniamy. Kharkiv - Ivano-Frankivsk: KhMAPO, 2020. 128 s.

7. Coronavirus disease pandemia 2019: growth of epidemic dangers / V.O. Shapovalova, S.I. Zbrozhek, V.V. Shapovalov, V.V. Shapovalov. Acta scientific pharmaceutical sciences. 2020. V. 4. Issue 7. P. $61-68$.

8. Shapovalov V.V., Shapovalova V.O., Shapovalov V.V. et al. Medychne ta farmatsevtychne pravo: navch. posib. dlia studentiv dennoi ta zaochnoi formy navchannia. Seriia «Medychne ta farmatsevtychne pravo». 3-ye vyd. zi zminamy ta dopovnenniamy. Kharkiv - Kyiv: KhMAPO, 2020. 128 s.

9. Shapovalova V.O., Shapovalov V.V., Osyntseva A.O. et al. Onovlennia medychnoho hlosariiu na zasadakh farmatsevtychnoho prava ta dokazovoi farmatsii. Suchasni napriamky udoskonalennia farmatsevtychnoho zabezpechennia naselennia: vid rozrobky do vykorystannia likarskykh zasobiv pryrodnoho i syntetychnoho pokhodzhennia: materialy naukovo-praktychnoi dystantsiinoi konferentsii $\mathrm{z}$ mizhnarodnoiu uchastiu, prysviachenoi 75-y richnytsi Universytetu ta 20-y richnytsi stvorennia farmatsevtychnoho fakultetu, m. Ivano-Frankivsk, 19-20 travnia $2020 \mathrm{r}$. Iv.-Fr., 2020. S. 71-72.

10. Shapovalova V.O., Shapovalov V.V., Shapovalov V.V. et al. Distance teaching of medical and pharmaceutical law in the system of postgraduate education of doctors and pharmacists in quarantine conditions. Organization of scientific research in modern conditions 2020: conference proceedings. Seattle: KindleDP in conjunction with the «ISE\&E» \& SWorld, 2020. P. 180-184. URL: https://www.sworld.com.ua/konferus02/sbor-us2.pdf.

11. Law of Ukraine "Fundamentals of the legislation of Ukraine on health care". URL: https://zakon.rada.gov.ua/laws/show/2801-12.

12. Constitution of Ukraine. URL: https://zakon.rada.gov.ua/laws/show/254\%D0\%BA/96-\%D0\%B2\%D1\%80\#Text.

13. Resolution adopted by the UN General Assembly on the $25^{\text {th }}$ of September, 2015 No. 70/1 "Transforming our world: the 2030 Agenda for Sustainable Development". URL: https://undocs.org/en/A/RES/70/1.

14. International Bill of Human Rights. UNO. URL: https://undocs.org/en/A/RES/217(III).

15. Law of Ukraine "On Higher Education". URL: https://zakon.rada.gov.ua/laws/show/1556-18. 
16. Code of Labor Laws of Ukraine. URL: https://zakon.rada.gov.ua/laws/show/322-08.

17. Code of Ukraine on Administrative Offenses. URL: https://zakon.rada.gov.ua/laws/show/80731-10.

18. Criminal Code of Ukraine. Verkovna Rada of Ukraine. 2001. №25-26, ст. 131 URL: https://zakon.rada.gov.ua/laws/show/2341-14.

19. Holovatyi S. Mirylo pravovladdia. Komentar. Hlosarii. Rule of Law Checklist. Київ: BAITE, 2017. 163 с.

20. Hotsuliak Ye. Sud vyznav vynnym likaria, yakyi napysav nepravdyvyi diahnoz pryzovnyku dlia unyknennia viiskovoi sluzhby. ArmiiaInform. 15.04.2021. URL: https://armyinform.com.ua/2021/04/sud-vyznav-vynnym-likarya-yakyj-napysavnepravdyvyj-diagnoz-pryzovnyku-dlya-unyknennya-vijskovoyi-sluzhby.

21. Neschetna S. Koly patsiientka zvernulasia do politsii, stomatoloh namahavsia yii vbyty: u Kyievi sudiat likaria-shakhraia. TSN.10.04.2021. URL: https://kyiv.tsn.ua/koli-paciyentka-zvernulasya-do-policiyi-stomatolog-namagavsyayiyi-vbiti-u-kiyevi-sudyat-likarya-shahraya-1762003.html.

22. Smolnytska K. Pererizav halmivnyi shlanh u mashyni teshchi: u Kyievi likariustomatolohu povidomleno pro pidozru u shche odnomu zamakhu na vbyvstvo. TSN. 09.06.2021. URL: https://kyiv.tsn.ua/pererizav-galmivniy-shlang-u-mashini-teschi-ukiyevi-likaryu-stomatologu-povidomleno-pro-pidozru-u-sche-odnomu-zamahu-navbivstvo-1800730.html.

23. Stolychnoho likaria-stomatoloha obvynuvachenoho $\mathrm{u}$ vchynenni riadu zlochyniv, sudytyme sud prysiazhnykh. Kyiv City Prosecutor's Office. https://kyiv.gp.gov.ua/ua/news.html? m=publications\&_c=view\&_t=rec\&id=298572 24. Stolychnoho likaria-stomatoloha pidozriuiut $\mathrm{u}$ zamakhu na vbyvstvo, rozbiinykh napadakh ta shakhraistvi na 400 tys. hryven. Kyiv City Prosecutor's Office.

URL: https://kyiv.gp.gov.ua/ua/news.html? m=publications\&_c=view\&_t=rec\&id=291375 25. Berezhna S., Prokopenko I. Higher Education Institutions in Ukraine during the Coronavirus, or COVID-19, Outbreak: New Challenges vs New Opportunities // Revista Romaneasca pentru Educatie Multidimensionala. - 2020. - Vol. 12, Is. 1 Sup. 2. - P. 130-135.

26. Smokovych M. Legal education in the conditions of distance learning. Entrepreneurship, Economy and Law. 2021. №2. P. 181-184. URL: http://pgpjournal.kiev.ua/archive/2021/2/34.pdf. $\quad$ DOI: https://doi.org/10.32849/26635313/2021.2.33.

27. Bulychev A.O., Havryliuk L.V. Pedahohichni umovy vprovadzhennia dystantsiinoho navchannia $\mathrm{v}$ zakladakh vyshchoi osvity zi spetsyfichnymy umovamy navchannia, yaki zdiisniuiut pidhotovku politseiskykh. Polish science journal. Warsaw: Sp.zo.o., "iScience", 2020. S. 26-29. URL: https://elibrary.kubg.edu.ua/id/eprint/33770/1/N_Bulycheva_A_Bulychev_L_Gavryl yuk_PSJ_9_KUBG.pdf

28. Owen P. Hall. Editorial: COVID-19 and the Future of Management Education - 2020. - Vol. 23. - Is. 1. - P. 1-12. 
29. Haiduchok I. H., Shapovalova V.O., Shapovalov V.V., Shapovalov V.V. Rezhym kontroliu likarskykh zasobiv dlia farmakoterapii koronavirusnoi khvoroby (COVID-19) u khvorykh na systemni zakhvoriuvannia. Informatsiinyi lyst pro novovvedennia $\mathrm{v}$ sferi okhorony zdorovia. Kyiv. 2020. № 225 - 2020. 8 s.URL: https://medinstytut.lviv.ua/wp-content/uploads/pdf/Informatsiynyy-lyst.pdf.

30. Zbrozhek S. Medical and pharmaceutical legislation: normative and legal regulation of healthcare specialists' activities in Finland. SSP Modern Pharmacy and Medicine. 2021. Vol. 1. N. 1. P. 1-8. URL: https://doi.org/10.53933/sspmpm.v1i1.5. 31. Berezovska L.I., Feher A.I. Rol sotsialnykh merezh u psykholohichnomu blahopoluchchi osobystosti. Psykholoho-pedahohichnyi suprovid profesiinoi pidhotovky ta pidvyshchennia kvalifikatsii fakhivtsiv $\mathrm{v}$ umovakh transformatsii osvity: materialy IKh Mizhnarodnoi naukovo-praktychnoi konferentsii (18 hrudnia 2020 r., m. Kyiv). Kyiv: DZVO «UMO», 2021. S. 13-17. URL: http://umo.edu.ua/images/content/institutes/imp/vydannya/konferenc/\%D0\%97\%D0 \%B1\%D1\%96\%D1\%80\%D0\%BD\%D0\%B8\%D0\%BA_\%D0\%BC\%D0\%B0\%D1\% 82\%D0\%B5\%D1\%80 \%D0\%BA\%D0\%BE\%D0\%BD\%D1\%84 2021\%20(psiholog $2 . \mathrm{pdf}$.

32. Kushnirenko K.O. Dystantsiine navchannia yak mozhlyvyi chynnyk psykholohichnoho dyskomfortu. Psykholoho-pedahohichnyi suprovid profesiinoi pidhotovky ta pidvyshchennia kvalifikatsii fakhivtsiv $\mathrm{v}$ umovakh transformatsii osvity: Materialy IKh Mizhnarodnoi naukovo-praktychnoi konferentsii (18 hrudnia 2020 r., m. Kyiv). Kyiv: DZVO «UMO», 2021. S. 123-126. URL: http://umo.edu.ua/images/content/institutes/imp/vydannya/konferenc/\%D0\%97\%D0 \%B1\%D1\%96\%D1\%80\%D0\%BD\%D0\%B8\%D0\%BA_\%0\%BC\%D0\%B0\%D1\% 82\%D0\%B5\%D1\%80_\%D0\%BA\%D0\%BE\%D0\%BD\%D1\%84_2021\%20(psiholog $2 . \mathrm{pdf}$.

33. Haidukevych K.A., Holovenko M.S. Vitchyzniani kulturni praktyky v umovakh pandemii COVID-19. Filosofiia podiievoi kultury: istoriia ta suchasnist: materialy Vseukr. nauk.- prakt. konf. (25-26 bereznia 2021 r. m. Kyiv), m. Kyiv, 2021. S. 35-37. URL: http://knukim.edu.ua/wpcontent/uploads/2021/03/Zbirnyk_Filosofiya_podievoi_kul_tury.

34. Karasiuk V.V., Bakumenko V.B., Klykov O.I. Vykorystannia tekhnolohii dystantsiinoho navchannia v NIuU im. Yaroslava Mudroho. Dystantsiina osvita: realii ta perspektyvy: materialy I vseukrainskoi naukovo-praktychnoi konferentsii (12 hrudnia 2018 r., m. Kharkiv). Kharkiv: KhNPU imeni H.S. Skovorody, 2018. S. $27-$ 29.

35. Kauk V.I., Hrebeniuk V.O. Yakist ta interes - osnovni konkurentni perevahy dystantsiinoho navchannia. Dystantsiina osvita: realii ta perspektyvy: materialy I vseukrainskoi naukovo-praktychnoi konferentsii (12 hrudnia, 2018r.,m.Kharkiv). Kharkiv: KhNPU imeni H. S. Skovorody, 2018. S. 30-33.

36. Brammer S., Clark T. COVID-19 and Management Education: Reflections on Challenges, Opportunities, and Potential Futures // British Journal of Management. 2020. - Vol. 31. - P. 453-456. 
37. Shapovalov V., Butko L., Shapovalov V. Organizational and legal study of quarantine restrictions in the spread of coronavirus disease in Ukraine. SSP Modern Pharmacy and Medicine. 2021. Vol. 1. N. 2. P. 1-12. URL: https://doi.org/10.53933/sspmpm.v1i2.23. 